AperTO - Archivio Istituzionale Open Access dell'Università di Torino

\title{
Sex determining of cat embryo and some feline species
}

\section{This is the author's manuscript}

Original Citation:

Availability:

This version is available http://hdl.handle.net/2318/137725

since

Published version:

DOI:10.1017/S0967199408004681

Terms of use:

Open Access

Anyone can freely access the full text of works made available as "Open Access". Works made available under a Creative Commons license can be used according to the terms and conditions of said license. Use of all other works requires consent of the right holder (author or publisher) if not exempted from copyright protection by the applicable law. 


\title{
Sex determining of cat embryo and some feline species
}

\author{
Francesca Ciani ${ }^{1,2}$, Natascia Cocchia ${ }^{3}$, Maria Rizzo ${ }^{2}$, Patrizia Ponzio ${ }^{4}$, Gennaro Tortora ${ }^{3}$, \\ Luigi Avallone ${ }^{2}$ and Roberto Lorizio ${ }^{3}$ \\ Department of Biological Structures, Functions and Technologies, University of Naples and Department of Veterinary \\ Clinic Sciences, University of Torino, Italy
}

Date submitted: 22.06.07. Date accepted: 24.09.07

\section{Summary}

Sex identification in mammalian preimplantation embryos is a technique that is used currently for development of the embryo transfer industry for zootechnical animals and is, therefore, a resource for biodiversity preservation. The aim of the present study was to establish a rapid and reliable method for the sexing of preimplantation embryos in domestic cats. Here we describe the use of nested PCR identify Y chromosome-linked markers when starting from small amounts of DNA and test the method for the purpose of sexing different species of wild felids. To evaluate the efficiency of the primers, PCR analysis were performed first in blood samples of sex-known domestic cats. Cat embryos were produced both in vitro and in vivo and the blastocysts were biopsied. A Magnetic Resin System was used to capture a consistent amount of DNA from embryo biopsy and wild felid hairs. The results from nested PCR applied on cat blood that corresponded to the phenotypical sex. Nested PCR was also applied to 37 embryo biopsies and the final result was: 21 males and 16 females. Furthermore, $\beta$-actin was amplified in each sample, as a positive control for DNA presence. Subsequently, nested PCR was performed on blood and hair samples from some wild felines and again the genotyping results and phenotype sex corresponded. The data show that this method is a rapid and repeatable option for sex determination in domestic cat embryos and some wild felids and that a small amount of cells is sufficient to obtain a reliable result. This technique, therefore, affords investigators a new approach that they can insert in the safeguard programmes of felida biodiversity.

Keywords: Domestic cat, Embryo biopsy, Nested PCR, Sexing, Wild felids

\section{Introduction}

Much progress has been made in the last few years in the development of assisted reproductive techniques (ART) for species conservation (Pope et al., 1997).

Most wild felid species are classified as rare, vulnerable or endangered because of poaching and

\footnotetext{
${ }^{1}$ All correspondence to: F. Ciani. Department of Biological Structures, Functions and Technologies, University of Naples Federico II, Via F. Delpino, 1 - 80137 Naples, Italy. Tel: +39 81 2536103. Fax: +39 81 2536104. e-mail: ciani@unina.it

${ }^{2}$ Department of Biological Structures, Functions and Technologies, University of Naples Federico II, Via F. Delpino, 1 - 80137 Naples, Italy.

${ }^{3}$ Department of Veterinary Clinic Sciences, University of Naples Federico II, Via F. Delpino, 1 - 80137 Naples, Italy.

${ }^{4}$ Department of Animal Disease, University of Torino, Via L. Da Vinci, 44 - 10095 Grugliasco (TO), Italy.
}

habitat loss. In vitro fertilization (IVF), embryo transfer (ET), artificial insemination (AI) and gamete cryopreservation are potentially important ART by which to optimize captive breeding programmes of selected felid species. The domestic cat is often used as a model from which to develop these techniques (Pope, 2000; Spindler et al., 2006).

In the last few years, the application of ART in the domestic cat has allowed researchers to obtain $70 \%$ of oocytes at metaphase II after in vitro maturation (IVM) (Pope et al., 2006), of which $80 \%$ developed to cleaved embryos after IVF and $70-80 \%$ after intracytoplasmic sperm injection (ICSI). (Comozzoli et al., 2006). Following in vitro culture (IVC) only $10 \%$ of total cleaved embryos developed to blastocyst after IVF and only 15-20\% after ICSI (Wood et al., 1995; Wood \& Wildt, 1997; Freistedt et al., 2001; Comozzoli et al., 2006). Kittens have been born after the transfer of IVM/IVF-derived embryos (Pope et al., 2000). Despite 
the relatively rapid development and adoption of in vitro embryo production, in vivo embryo collection remains the most popular technique for the production of embryos.

It has been demonstrated that the domestic cat can also serve as a successful recipient of embryos from closely related small non-domestic cats, as shown by the birth of Indian desert cat and African wildcat kittens after the transfer of IVF-derived embryos in female domestic cats (Pope et al., 1997). Recently, Gomez et al. (2004) produced African wildcat kittens after the transfer of embryos derived by fusion of adult somatic cells from one species with enucleated oocytes of a closely related species (domestic cat).

The sex determination of preimplantation embryos is a valuable method in ART by which to improve safeguard programmes for endangered felid species.

Several methods are available to determine sex at the cellular level. Cytological methods have been used since 1967, when cells from rabbits were scanned for Barr bodies (Edwards \& Gardner, 1967). Another procedure is 'in situ' hybridization, in which chromosome-specific DNA probes are hybridized to nuclei. In the early 1990s, the development of the polymerase chain reaction (PCR) opened up new possibilities for embryo sexing. Sex determination in mammals was first performed on blood cells from several species using the PCR reaction (Aasen \& Medrano, 1990). Subsequently, several studies were undertaken to determine the sex of ruminant embryos (Peura et al., 1991; Appa Rao et al., 1993; Macháty et al., 1993; Shea, 1999; Lopes et al., 2001; Park et al., 2001; Manna et al., 2003), and subsequently other authors performed splitting procedures (Leoni et al., 2000; Lopes et al., 2001). At first, sexing was applied to whole embryos (Appa Rao et al., 1993; Manna et al., 2003) and only subsequently on embryo biopsy (Bredbacka et al., 1995).

The potential of this method has been demonstrated in several species, which include humans (Handyside et al., 1989), cattles (Herr et al., 1990; Peura et al., 1991; Kirkpatrick \& Monson, 1993; Macha'ty et al., 1993; Collins et al., 1995; Thibier \& Nibart, 1995), horses (Peippo et al., 1995), sheep (Herr et al., 1990; Bredbacka \& Peippo, 1992), pigs (Fajfar-Whetstone et al.,1993; Ford \& Conley, 1994) and mice (Kunieda et al., 1992). To date, no sexing method for felida species that uses PCR has been reported in the literature.

PCR allows the amplification of $X$ and $Y$ chromosome-specific sequences in order to determine the sex of embryos in a relatively short time and with high reliability (Macháty et al., 1993; Grifo et al., 1997; Bredbacka, 1998; Greenlee et al., 1998; Shea, 1999; Park et al., 2001).

Several approaches to sex determination involve the co-amplification of a Y-chromosomal sequence, commonly found in mammals. (Manna et al., 2003).
This approach requires a small amount of DNA, be fast, efficient and accurate, and allows embryos to be transferred immediately into recipient females without the need for further storage.

The aims of this study were firstly to develop a rapid and reliable method for the sex determination of preimplantation cat embryos in domestic cats by the use of nested PCR and in order to identify $Y$ chromosome-linked markers when starting from small amounts of DNA, and then to apply the same method to identify the sex of some wild felids.

To establish the sensitivity of the method we first tested the procedure on autosomal cells by the use of both female and male blood samples of adult cats and blood or hair of male and female wild felids; the technique was then applied to embryos using only a few cells from blastocysts produced in vitro and in vivo.

\section{Materials and methods}

To test the efficiency of nested PCR in order to differentiate female and male sex, blood samples were obtained from domestic cats of known sex. Next, the method was applied to domestic cat embryos produced in vitro and in vivo. Furthermore, blood and hair samples of some wild felids of both sexes were tested with nested PCR.

\section{Blood and hair samples}

Blood samples were collected from four male and four female domestic cats in the clinic as controls to verify if the primers chosen were able to differentiate male and female sexes.

In addition, blood and hairs were collected from the following wildcats resident at Naples Zoo: two Panthera pardus (blood of one male and one female); two Panthera leo (hairs of one male and one female); two Puma concolors (hairs of one male and one female); two Panthera onca (blood of one male and one female).

All samples were collected from domestic cats following the owners' agreements. It was possible to get samples from the zoo animals during routine clinical procedures, on the basis of a research agreement between the Veterinary Faculty and Naples Zoo.

\section{In vitro cat embryo production}

All chemical products used were purchased from Sigma-Aldrich, Italy.

\section{Oocytes collection and IVM}

Ovaries were collected from 20 sexually mature queens at various stages of their reproductive cycle and following routine ovariohysterectomy at local veterinary clinics. During transport, ovarian pairs 
were stored in Dulbecco's phosphate-buffered saline (D-PBS plus $100 \mathrm{IU} / \mathrm{ml}$ penicillin and $100 \mathrm{mg} / \mathrm{ml}$ streptomycin) at $34^{\circ} \mathrm{C}$. Within $2 \mathrm{~h}$ of excision, ovaries were minced and the oocytes were liberated into $38^{\circ} \mathrm{C}$ D-PBS. (Spindler et al., 2006; Herrick, 2007). Each ovary was sliced repeatedly with a scalpel blade to release cumulus-oocyte complexes (COCs) into a 90-mm culture dish containing tissue culture medium (TCM199) with $25 \mathrm{mM}$ HEPES supplemented with $4 \mathrm{mg} / \mathrm{ml}$ bovine serum albumin (BSA). Only COCs that exhibited uniform, dark-pigmented ooplasm and an intact cumulus cell investment were used for further culture (Wood \& Wildt, 1997). We collected COCs immediately after recovery. COCs were cultured separately in $500 \mu \mathrm{l}$ drops of maturation medium (12-20 COCs/drop) in 4-well dishes for $24 \mathrm{~h}$. The maturation medium consisted of TCM-199 with Earle's salts, supplemented with $0.4 \%$ BSA, $2.6 \mathrm{mg} / \mathrm{ml}$ pyruvate, $0.075 \mathrm{mg} / \mathrm{ml}$ kanamycin, $0.1 \mathrm{IU} / \mathrm{ml} \mathrm{FSH}, 10$ $\mathrm{IU} / \mathrm{ml} \mathrm{LH}$ and $1 \mu \mathrm{g} / \mathrm{ml}$ estradiol (Spindler et al., 2006; Herrick, 2007). All cultures were preformed for $32 \mathrm{~h}$ at $38^{\circ} \mathrm{C}$ in a humidified environment of $5 \% \mathrm{CO}_{2}$ in air.

\section{Spermatozoa collection and IVF}

Spermatozoa for IVF were collected from adult male cat epididymis following castration at local veterinary clinics. The testes with their epididymies were kept in physiological saline and maintained at room temperature until spermatozoa collection. Each epididymis was separated, removed from its testes and sliced repeatedly with a scalpel blade to release spermatozoa into a 90-mm culture dish containing $\mathrm{m}$ PBS at $37^{\circ} \mathrm{C}$. The released spermatozoa were washed with $\mathrm{m}$-PBS and centrifuged at $1200 \mathrm{rpm}$ for $5 \mathrm{~min}$. The supernatant was removed and the sperm pellet was evaluated. The spermatozoa concentration was adjusted to $4 \times 10^{6}$ spermatozoa/ml in the Fert-TALP (Izquierdo et al., 1999) and then further diluted with additional Fert-TALP medium supplemented with $0.6 \% \mathrm{BSA}, 2.2 \mathrm{mg} / \mathrm{ml}$ sodium pyruvate, $0.075 \mathrm{mg} / \mathrm{ml}$ kanamycin and $20 \mathrm{mg} / \mathrm{ml}$ heparin to a final concentration of $2 \times 10^{6}$ spermatozoa/ml. After $24 \mathrm{~h}$ in vitro maturation, the oocytes were transferred into $500 \mathrm{ml}$ drop that contained the sperm (15-20 COCs/drop) for fertilization and were coincubated for $24 \mathrm{~h}$. After $24 \mathrm{~h}$ of coincubation with spermatozoa, cumulus cells surrounding zygotes were removed by vortexing (Herrick et al., 2007). The denuded zygotes were cultured in wells containing synthetic oviductal fluid (SOF) that was supplemented with $0.8 \%$ BSA, $0.036 \mathrm{mg} / \mathrm{ml}$ sodium pyruvate, $0.075 \mathrm{mg} / \mathrm{ml}$ kanamycin sulfate, $10 \mathrm{mg} / \mathrm{ml}$ non-essential amino acid and $10 \mathrm{mg} / \mathrm{ml}$ essential amino acids (AA) and incubated at $38^{\circ} \mathrm{C}$ under a $5 \% \mathrm{CO}_{2}, 5 \% \mathrm{O}_{2}$ and $90 \%$ $\mathrm{N}_{2}$ gas mixture for 7 days. Days 3 and 5 embryos were transferred to fresh SOF + BSA + essential and non-essential AA with $0.8 \%$ BSA. On day 7 of in vitro culture (IVC) the number of embryos that developed to the blastocyst stage was determined visually and all embryos were classified into three stages: (1) 2-16 cells; (2) morula (16-50 cells); (3) blastocyst (>50 cells with blastocelic cavity) (Bogliolo et al., 2001).

\section{In vivo cat embryo production}

Three cyclic non-pregnant cat donors, between 9 and 26 months old, were selected after clinic examination and confirmation of anestrus. These experiments were performed with the owners' agreements.

Mature anestrus females were injected with PMSG (150 IU) and 96h later with hCG (100 IU). Each superovulated cat stayed with an adult fertile male cat for $24 \mathrm{~h}$ to allow mating. For the following 7 days each female cat was fed ad libitum and was put in a quiet, comfortable and familiar environment. At the end of the seventh day each female cat was ovary isterectomized and the uterus was immediately plunged in the PBS solution at $37^{\circ} \mathrm{C}$. Next, the uterus was flushed with $\mathrm{SOF}$ and the recovered embryos were evaluated and frozen (Kajta, 1998; Herrick et al., 2007).

A total of 37 embryos were obtained: 20 embryos at different development stages were collected in vivo and 18 blastocysts were produced in vitro.

\section{Embryo biopsy}

Compacted morulae and blastocysts were biopsied manually with a microblade and according to a simplified protocol (Bredbacka et al., 1995). The employed slice was a cut from a razor blade (Gilette) and glued onto a glass tube using acrylic glue. The size of the edge was approximately $5 \mathrm{~mm}$. The biopsy was put into a $100-200 \mathrm{ml}$ drop of PBS supplemented with $4 \mathrm{mg} / \mathrm{ml}$ polyvinylpyrrolidone (PBS + PVP) in the a $35-\mathrm{mm}$ plastic Petri dish. Blastocysts were biopsied by slight pressure over the embryo, leaving the inner cell mass intact. The biopsy size was about $25 \%$ of the total embryonic cell mass. After this biopsy the blade was moved to one side until a biopsy of desired size could be separated from the embryo. To avoid the situation that spermatozoa DNA could contaminate the zona pellucida, and therefore contaminate the assay, the blastomeres were removed by aspiration after microdissection of the zona pellucida and the collected cells were rinsed several times. Each sample was frozen in microdrop container and maintained at $-20^{\circ} \mathrm{C}$ until the experiments were performed.

\section{Polymerase chain reaction}

\section{DNA purification from blood and hairs}

DNA was purified from $200 \mu \mathrm{l}$ whole blood using a QIA-amp Kit (Qiagen). Briefly, $25 \mu \mathrm{l}$ of proteinase K was added to the samples and incubated at $70^{\circ} \mathrm{C}$ for $10 \mathrm{~min}$. After digestion, samples were loaded on a QIAamp spin column binding specifically the DNA. The 


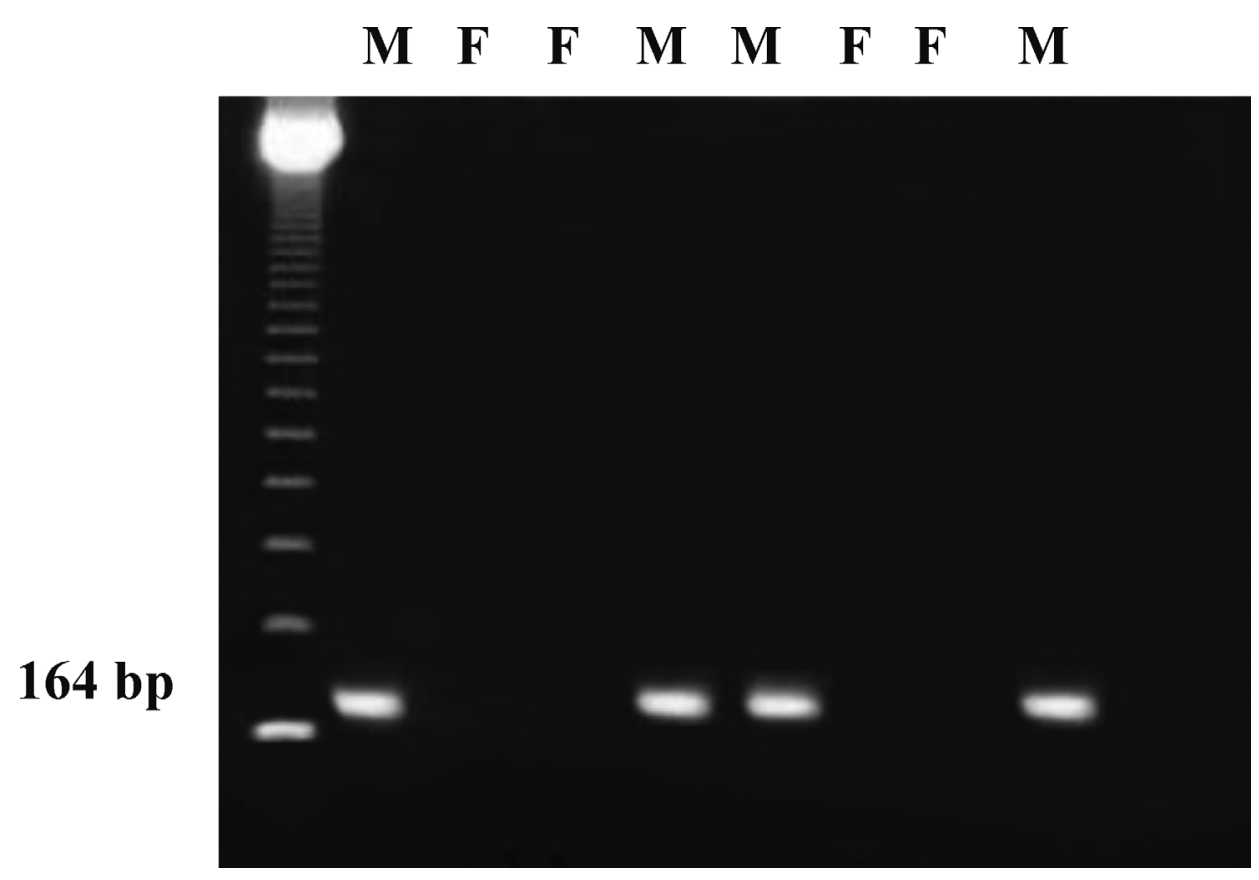

Figure 1 Electrophoretic presentation of nested PCR products amplified from white blood cells from sex-known domestic cats. The 164 bp band was present in males and but not in females. M: male; F: female.

membrane was washed three times and the DNA was eluted in $200 \mu \mathrm{l}$ of distilled water preheated to $70^{\circ} \mathrm{C}$.

DNA purification from embryo biopsy

A magnetic resin system (Promega) was used to capture a consistent amount of DNA. Samples were incubated at $95^{\circ} \mathrm{C}$ for $30 \mathrm{~min}$ with a lysis buffer, then mixed with an appropriate amount of paramagnetic resin. Samples were incubated at room temperature for $5 \mathrm{~min}$ and placed in the magnetic stand for resin separation. After several washes, DNA was eluted in $100 \mu 1$ of elution buffer.

\section{Nested polymerase chain reaction}

Nested PCR amplification of the sex-determining region $\mathrm{Y}$ gene (SRY) was used to identify $\mathrm{Y}$ chromosome-linked markers for sex determination, using small amounts of DNA only. The SRY box is ubiquitous and highly conserved across mammalian orders. The outer primers used were: SRYA1 (5'-cgtcaaacgacccatgaacgc- $\left.3^{\prime}\right)$ and SRYA2 (5'-atagcccgggtatttctctc- $\left.3^{\prime}\right)$. The nested primers were: SRYB3 (5'-gaacgcattcatggtgtggtc- $\left.3^{\prime}\right)$ and SRYB4 (5'-gcctgtagtctctgtgcctcc- $\left.3^{\prime}\right)$ (CEINGE, Naples).

Amplifications were carried out in a programmed thermal cycler (Biometra). The conditions of the first amplification (SRYA1/SRYA2) were: initial denaturation at $95^{\circ} \mathrm{C}(3 \mathrm{~min})$, followed by 35 cycles at $95^{\circ} \mathrm{C}(1 \mathrm{~min}), 60^{\circ} \mathrm{C}$ annealing $(30 \mathrm{~s})$ and $72^{\circ} \mathrm{C}$ extension (1 min), with a final extension at $72{ }^{\circ} \mathrm{C}$ for $10 \mathrm{~min}$. The second amplification (SRYB3/SRYB4) was performed under the same conditions.
The first PCR reactions were performed using $1 \mu \mathrm{l}$ of DNA in a total volume of $50 \mu \mathrm{l}$ in the presence of: 10 pmol of each oligonucleotide primer, $200 \mathrm{mM}$ dNTP, $5 \mu \mathrm{l}$ of $10 \times$ PCR buffer, $1.5 \mathrm{mMmgCl}_{2}$ and $1.25 \mathrm{U}$ Taq polymerase. For the nested PCR, $1 \mu \mathrm{l}$ of each reaction was reamplified in presence of the nested primers.

Another pair of primers, specific to a fragment of $\beta$ actin gene, was also amplified and used as the control for the presence of DNA. The interpretation of the PCR assay is valid only if the PCR control band (442 bp) is observed on the gel after amplification. The absence of this band in the sample reveals either a problem of amplification or absence of the cell sampling. Therefore no interpretation can be done in the absence of the control band (442 bp).

The primer sequences for $\beta$-actin were: sense $5^{\prime}$ tgactacctcatgaagatcct-3'; antisense: $5^{\prime}$-gaggagcaatgatcttgat $-3^{\prime}$. The conditions for the amplification of $\beta$-actin were: initial denaturation was at $95^{\circ} \mathrm{C}(3 \mathrm{~min})$, followed by 35 cycles at $95^{\circ} \mathrm{C}(1 \mathrm{~min}), 65^{\circ} \mathrm{C}$ annealing $(30 \mathrm{~s})$ and $72{ }^{\circ} \mathrm{C}$ extension $(1 \mathrm{~min})$, with a final extension at $72^{\circ} \mathrm{C}$ for $10 \mathrm{~min}$. After amplification, $\mathrm{PCR}$ products were subjected to size separation by agarose gel electrophoresis $(18 \mathrm{~g} / \mathrm{l})$ and visualized with UV transilluminator.

\section{Results}

To differentiate male and female sexes in domestic cats, we performed a nested PCR on eight blood samples from eight domestic cats of known sex. Figure 1 shows a 


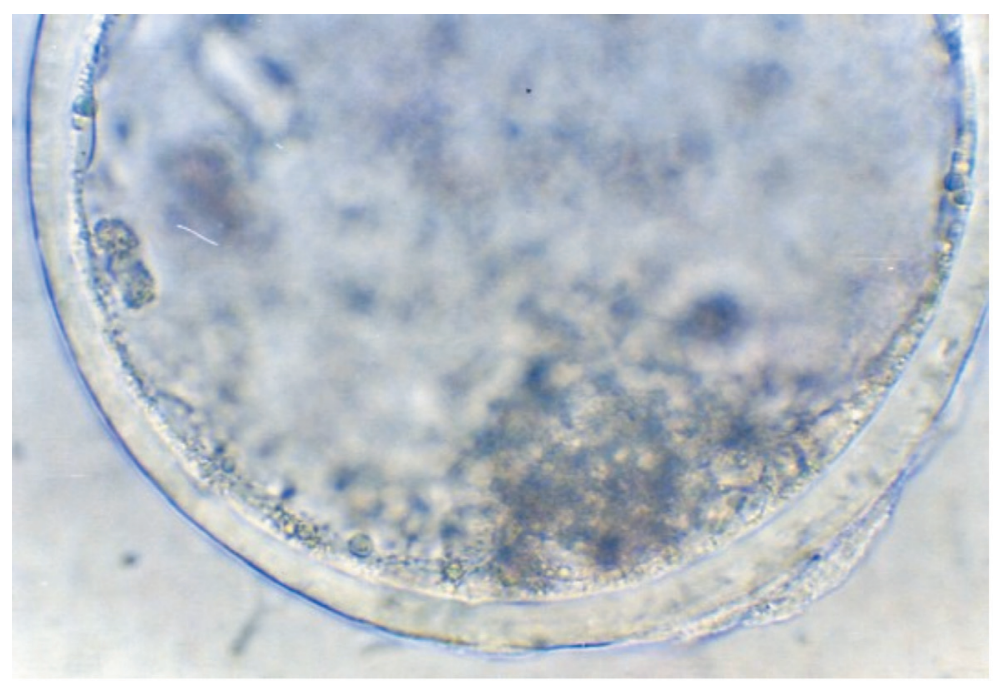

$\mathbf{a}$

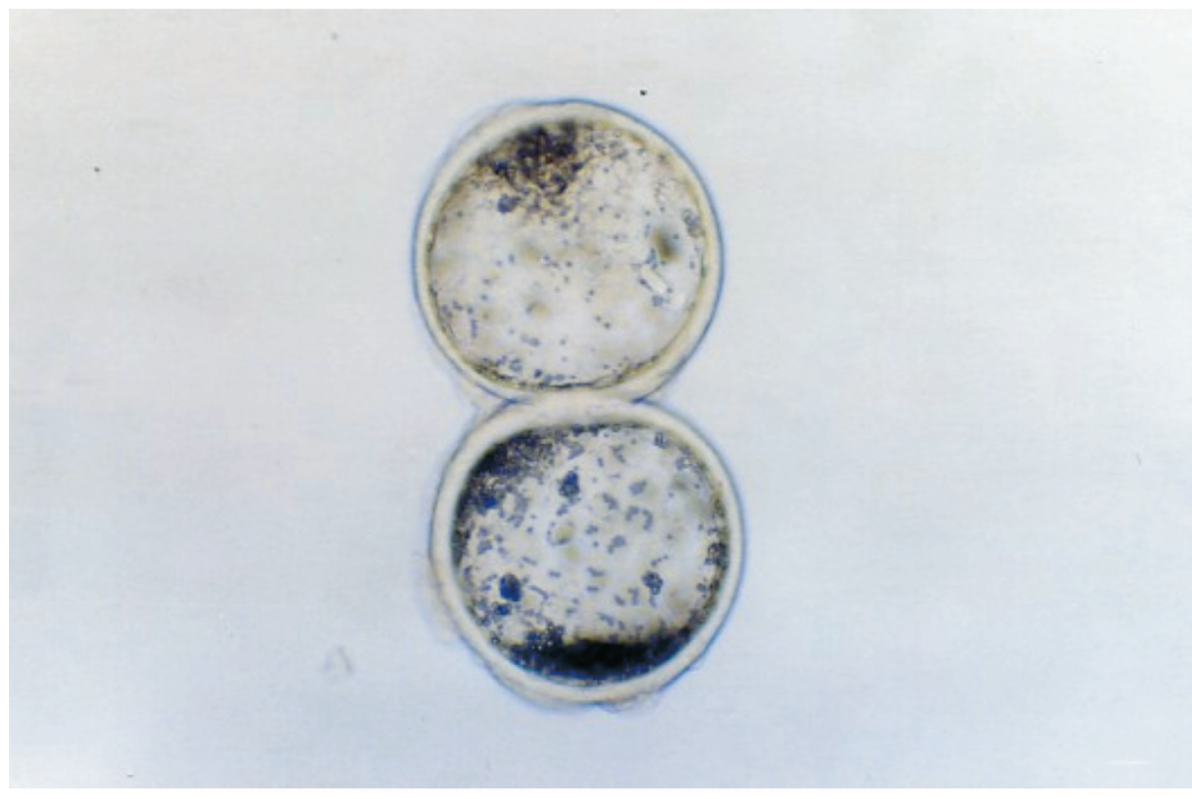

b

Figure $2(a)$ Feline blastocyst (magnification $\times 40)$; $(b)$ two feline blastocysts (magnification $\times 10$ ).

band of $164 \mathrm{bp}$ in the male domestic cats (four samples) and no evidence of a band in female samples. Actin was also amplified in each sample to control for the presence of DNA (control for false negatives).

Figure 2 shows blastocysts of domestic cats. Figure 3 reports the results of nested PCR of ten embryos, of which four were males (positive for the presence of a $164 \mathrm{bp}$ band) and six were female (no $164 \mathrm{bp}$ band). A total of 37 embryos was used for the determination of sex. Nested PCR was applied to every sample and the final result was: 21 males and 16 females.
Furthermore, the control $\beta$-actin was also amplified in each sample, DNA presence (control for false negative).

Blood and hair of some wild felids were subjected to nested PCR in order to evaluate the efficiency of the primers that were used in domestic cat to identify the SRY region in the test species. The results are reported in Figs. 4 and 5. The 164 bp bands presented in Fig. 4 correspond to three male wild felids (Panthera pardus, Panthera leo, Puma concolor). The corresponding females presented no $164 \mathrm{bp}$ band. Figure 5 shows the presence 


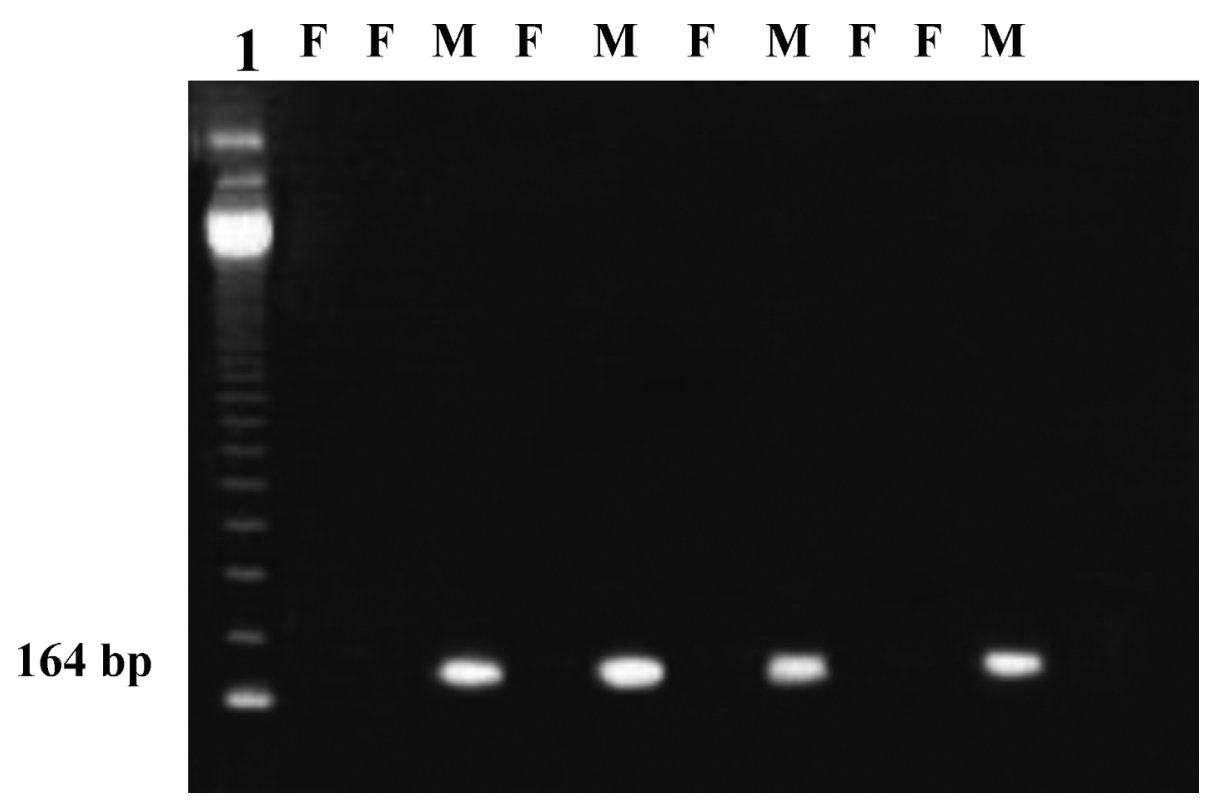

Figure 3 Electrophoretic representation of nested PCR products amplified from biopsied blastocysts. The 164 bp band was present in males and but not in females. Lane 1: 123 ladder; M: male; F: female.

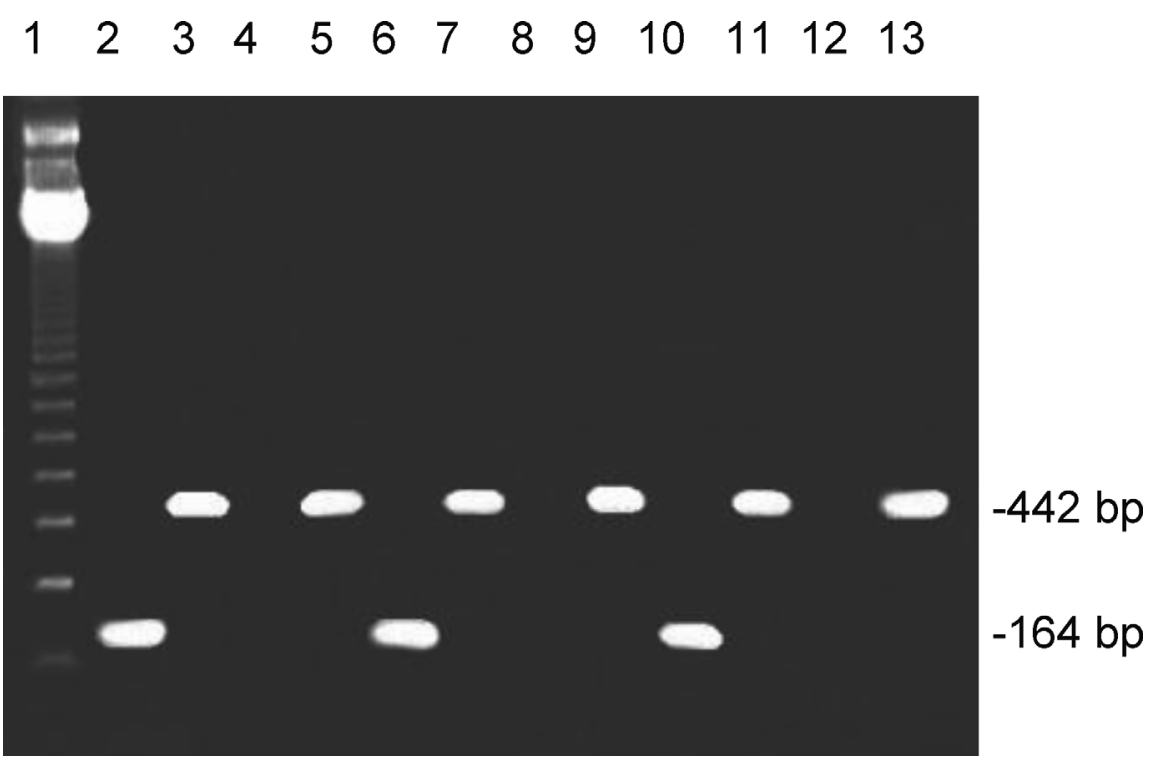

Figure 4 Electrophoretic representation of nested PCR products amplified from blood or hairs of sex-known wild felids. The $164 \mathrm{bp}$ band was present in males and but not in females. The $442 \mathrm{bp}$ band ( $\beta$-actin) is positive in every sample (control for false negatives). Lane 1: 123 ladder; 2: male (Panthera pardus); 3: male $\beta$-actin (Panthera pardus); 4: female (Panthera pardus); 5: female $\beta$-actin (Panthera pardus); 6: male (Panthera leo); 7: male $\beta$-actin (Panthera leo); 8: female (Panthera leo); 9: female $\beta$-actin (Panthera leo); 10: male (Puma concolor); 11: male $\beta$-actin (Puma concolor); 12: female (Puma concolor); 13: female $\beta$-actin (Puma concolor).

of a $164 \mathrm{bp}$ band in the male Panthera onca, while the $164 \mathrm{bp}$ band was absent in the female. Nested PCR was performed on blood from: two Panthera pardus, two Panthera onca; and from hairs of: two Panthera leo and two Puma concolor. The 442 bp band ( $\beta$-actin) is present in each sample (control for false negatives).

\section{Discussion}

The primary application of feline sexing is to determine accurately the sex of in vivo- and in vitro-produced cat embryos. It is necessary that the method ensures maximum embryo viability as only minimal DNA is obtained from embryonic cells. In the present study, 


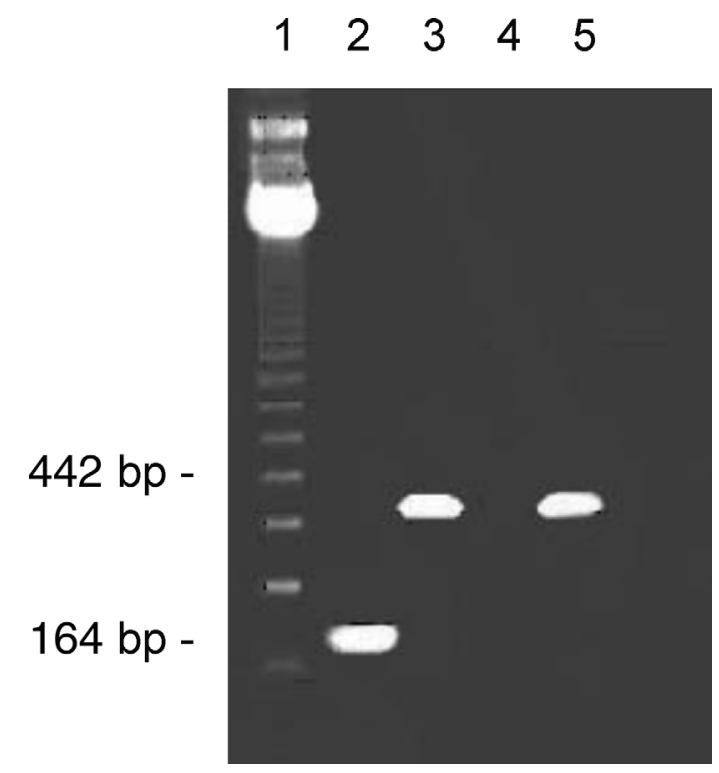

Figure 5 Electrophoretic representation of PCR products amplified from blood of sex-known wild felids (Panthera onca). The $164 \mathrm{bp}$ band was present in males and but not in females. The $442 \mathrm{bp}$ band ( $\beta$-actin) is positive in every sample (control for false negatives). Lane 1: 123 ladder; 2: male (Panthera onca); 3: male $\beta$-actin (Panthera onca); 4 : female (Panthera onca); 5: female $\beta$-actin (Panthera onca).

nested PCR was used to increase the sensitivity of the assay and $\mathrm{Y}$ chromosome-specific primers have been used for sex determination of domestic cat blood samples and embryos. The same method was utilized to isolate the SRY sequence in wild felids of both sexes: Panthera pardus, Panthera onca, Panthera leo, Puma concolor, using blood or hair samples.

Advances in domestic cat ART have enabled investigators to use similar techniques in some species of wild felids. Embryo sexing of wild felids is available and contributes to the protection of biodiversity for captive breeding programmes (Pelican et al., 2006).

The most common approach in sexing embryos involves the co-amplification of the $\mathrm{Y}$ chromosomespecific sequence, which contains the Y-linked genes (SRY) and an autosomal sequence that acts as a control for the presence of DNA (Peura et al., 1991; Appa Rao et al., 1993; Macháty et al., 1993; Park et al., 2001; Manna et al., 2003).

The method described here uses a primary PCR to amplify the SRY sequence. SRY is expressed ubiquitously and is highly conserved across mammalian orders. Reverse primers were chosen to anneal with conserved regions of SRY in order to differentiate SRY from related autosomic genes. In addition, we checked the sensitivity of primary PCR by nested PCR using SRY-B1 and SRY-B2 primers. The results indicate clearly that nested PCR is highly sensitive and enhances the specificity of the assay. Similar observations were reported with preimplantation embryos from other species (Handyside et al., 1989; Kunieda et al., 1992; Ford \& Conley, 1994; Collins et al., 1995; Peippo et al., 1995; Leoni et al., 2000; Chrenek et al., 2001; Mara et al., 2004). To date, no sexing method for felida species using PCR has been reported in the literature. Commercial PCR sexing protocols for bovine embryos that involve the use of Y-specific primers report a 90-95\% efficiency and a 93-95\% accuracy, depending on the biopsy procedure (Thibier \& Nibart, 1995).

The PCR primers used for the nested PCR reaction were designed to amplify a smaller fragment within the SRY sequence. Using nested primers, no evidence of non-specific nested amplification was observed.

The samples that did not show the amplified male specific product were interpreted as being from female embryos; however false sex determination could occur, as the absence of any amplified product may reflect the absence of embryonic DNA in the sample. To assess this possibility, the detection of autosomal DNA primers ( $\beta$-actin) was carried out in this study as a control, in addition to the detection of Y-specific sequences. This control facilitated the confirmation of the absence of blastomeres in the reaction mixture and the exclusion of false female results. When using control primers in the reaction, the presence of two bands, the first specific for the sex and the second for autosomal DNA, is interpreted as the embryo being male. When the malespecific band is absent and the autosomal specific band visible, the embryo is considered female. The lack of the two bands indicates the absence of cellular DNA in the sample, excluding false female results. As sexdetermined cat embryos were not transferred because of the non-availability of recipient cats, it was not possible to confirm the results directly.

DNA isolated from blood that was collected from both male and female domestic cats and wild felids was used as a template for the PCR, in order to evaluate the reliability of the sexing method. PCR-based sex determination using DNA from blood and hair of wild felids was in complete agreement with phenotypical sex.

The amplification bands indicated that the Yspecific amplification, detected by first primers, was confirmed by nested primers (in nearly all cases); this demonstrated the accuracy of the nested PCR sexing method.

The SRY gene region is conserved in domestic and non-domestic felids and a sensitive and efficient method for sexing cat embryos has been developed using nested PCR. This study is a useful adjunct to the technologies of in vitro maturation and fertilization and embryo transfer and these results may facilitate future studies in embryo sex differentiation, in transgenic animals and in fetal gene expression. 
Furthermore, embryo sexing has the advantage over other methods (i.e. sperm sexing) in that it can be applied in in vivo-obtained embryos. This method allows investigators to use fewer embryo cells, ensuring maximum embryo viability and can be effectively applied in wild feline.

These results confirm that the method can be used in feline assisted breeding programmes for the purpose of manipulating the sex ratios of offspring.

\section{References}

Aasen, E. \& Medrano, J.F. (1990). Amplification of the ZFY and ZFX genes for sex identification in human, cattle, sheep and goats. Biotechnology 8, 1279-81.

Appa Rao, J.K.C., Pawshe, C.H. \& Totey, S.M. (1993). Sex determination of in vitro developed buffalo (Bubalus bubalis) embryos by DNA amplification. Mol. Reprod. Dev. 36, 291-6.

Bogliolo, L., Leoni, G., Ledda, S., Naitana, S., Zedda, M., Carluccio, A. \& Pau, S. (2001). Intracytoplasmic sperm injection of in vitro matured oocytes of domestic cats with frozen-thawed epididymal spermatozoa. Theriogenology $56,955-67$.

Bredbacka, P. (1998). Recent developments in embryo sexing and its field application. Reprod. Nutr. Dev. 38, 605-13.

Bredbacka, P., Kankaanpaa, A. \& Peippo, J. (1995). PCR-sexing of bovine embryos: a simplified protocol. Theriogenology 44, 167-76.

Bredbacka, P. \& Peippo, J. (1992). Sex diagnosis of ovine and bovine embryos by enzymatic amplification and digestion of the DNA from the ZFY/ZFX locus. Agric. Sci. Finl. 2, 233-8.

Chrenek, P., Boulanger, L., Heyman, Y., Uhrin, P., Laurincik, J., Bulla, J. \& Renard, J.P. (2001). Sexing and multiple genotype analysis from a single cell of bovine embryo. Theriogenology 55, 1071-81.

Collins, M.E., Stevens, D.A., Jenner, L.J. \& Brownlie, J. (1995). A rapid method for rRNA detection in single cell biopsies from preimplantation-stage bovine embryos. Theriogenology 43, 1227-38.

Comizzoli, P., Wildt, D.E. \& Pukazhenthi, B.S. (2006). In vitro development of domestic cat embryos following intracytoplasmatic sperm injection with testicular spermatozoa. Theriogenology 66, 1659-63.

Edwards, R.G. \& Gardner, R.L. (1967). Sexing of live rabbit blastocysts. Nature 214, 576-7.

Farstard, W. (2000). Current state in biotechnology in canine and feline reproduction. Anim. Reprod. Sci. 60-1, 375-87.

Freistedt, P., Stojkovic, M. \& Wolf, E. (2001). Efficient in vitro production of cat embryos in modified synthetic oviduct fluid medium: effects of season and ovarian status. Biol. Reprod. 65, 9-13.

Ford, S.P. \& Conley, A.J. (1994). Effect of sex and recipient breed of porcine embryonic development. Biol. Reprod. 50, 88.

Gomez, M.C., Pope, C.E., Giraldo, A., Lyons, L.A., Harris, R.F., King, A.L., Cole, A., Godke, R.A. \& Dresser, B.L. (2004). Birth of African wildcat cloned kittens born from domestic cats. Cloning and Stem Cells 6, 247-58.
Greenlee, A.R., Krisher, R.L. \& Plotka, E.D. (1998). Rapid sexing of murine preimplantation embryos using a nested, multiplex polymerase chain reaction (PCR). Mol. Reprod. Dev. 49, 261-7.

Grifo, J.A., Tang, Y.X. \& Krey, L. (1997). Update in preimplantation genetic diagnosis. Ann. N Y Acad. Sci. 26, 162-5.

Handyside, A.H., Pattinson, J.K., Penketh, R.J.A., Delhanty, J.D.A., Winston, R.M.L. \& Tuddenham, E.G.D. (1989). Biopsy of human preimplantation embryos and sexing by DNA amplification. Lancet I, 347-9.

Herrick, J.R., Bond, J.B., Magarey, G.M., Bateman, H.L., Krisher, R.L., Dunford, S.A. \& Swanson, W.F. (2007). Toward a feline optimized culture medium: impact of ions, carbohydrates, essential amino acids, vitamins and serum on development and metabolism of in vitro fertilizationderived feline embryos relative to embryos grown in vivo. Biol. Reprod. [Epub ahead of print].

Herr, C.M., Matthaei, K.I., Bradley, M.P. \& Reed, K.C. (1990). Rapid accurate sexing of livestock embryos. Proceedings of 4th World Congress on Genetics Applied to Livestock Production XVI, 343.

Izquierdo, D., Villamediana, P. \& Paramio, M.T. (1999). Effect of culture media on embryo development from prepubertal goat IVM-IVF oocytes. Theriogenology 52, 847-61.

Kajta, M. (1998). Preovulatory dynamics of steroids demonstrated in vivo by ovarian follicles of cyclic and superovulated rat females. Endocr. Regul. 32, 43-50.

Kirkpatrick, B.W. \& Monson, R.L. (1993). Sensitive sex determination assay applicable to bovine embryos derived from IVM and IVF. J. Reprod. Fertil. 98, 335-40.

Kunieda, T., Xian, M., Kobayashi, E., Imamichi, T., Moriwaki, K. \& Toyoda, Y. (1992). Sexing of mouse preimplantation embryos by detection of $Y$ chromosome-specific sequences using polymerase chain reaction. Biol. Reprod. 46, 692.

Leoni, G., Ledda, S., Bogliolo, L. \& Naitana, S. (2000). Novel approach to cell sampling from preimplantation ovine embryos and its potential use in embryonic genome analysis. J. Reprod. Fertil. 119, 309-14.

Lopes, R.F.F., Forell, F., Oliveira, A.T.D. \& Rodrigues, J.L. (2001). Splitting and biopsy for bovine embryo sexing under field conditions. Theriogenology 56, 1383-92.

Macháty, Z., Páldi, A., Csáki, T., Varga, Z., Kiss, I., Bárándi, Z. \& Vajta, G. (1993). Biopsy and sex determination by PCR of bovine embryos. J. Reprod. Fertil. 98, 467-70.

Manna, L., Neglia, G., Marino, M., Gasparrini, B., Di Palo, R. \& Zicarelli, L. (2003). Sex determination of buffalo embryos (Bubalus bubalis) by polymerase chain reaction. Zygote 11, 17-22.

Mara, L., Pilichi, S., Sanna, A., Accardo, C., Chessa, B., Chessa, F., Dattena, M., Bomboi, G. \& Cappai, P. (2004). Sexing of in vitro produced ovine embryos by duplex PCR. Mol. Reprod. Dev. 69, 35-42.

Park, J.H., Lee, J.H., Choi, K.M., Joung, S.Y., Kim, J.Y., Chung, J.M., Jin, D.I. \& Im, K.S. (2001). Rapid sexing of preimplantation bovine embryos using consecutive and multiplex polymerase chain reaction (PCR) with biopsied single blastomeres. Theriogenology 55, 1843-53.

Peippo, J., Huhtinen, M. \& Kotilainen, T. (1995). Sex diagnosis of equine preimplantation embryos using the polymerase chain reaction. Theriogenology 44, 619-27. 
Pelican, K.M., Wildt, D.E., Pukazhenthi, B. \& Howard, J. (2006). Ovarian control for assisted reproduction in the domestic cat and wild felids. Theriogenology 66, 37-48.

Peura, T., Hyttinen, J.M., Turunen, M. \& Janne, J. (1991). A reliable sex determination assay for bovine preimplantation embryos using the polymerase chain reaction. Theriogenology 35, 547-55.

Pope, C.E. (2000). Embryo technology in conservation efforts for endangered felids. Theriogenology 53, 16374.

Pope, C.E., McRae, M.A., Plair, B.R., Keller, G.L. \& Dresser, B.L. (1997). In vitro ed in vivo development of embryos produced by in vitro maturation and in vitro fertilization of cat oocytes. J. Reprod. Fertil. Suppl. 51, 6982.

Pope, C.E., Gomez, M.C. \& Dresser, B.L. (2006). In vitro embryo production and transfer in domestic and nondomestic cats. Theriogenology 66, 1518-24.
Shea, B.E. (1999). Determining the sex of bovine embryos using polymerase chain reaction results: a six-year retrospective study. Theriogenology 51, 785-97.

Spindler, R.E., Crichton, E.G., Agca, Y., Loskutoff, N., Crister, J., Gardner, D.K. \& Wildt, D.E. (2006). Improved felid embryo development by group culture is maintained with heterospecific companions. Theriogenology 66, 8292.

Thibier, M. \& Nibart, M. (1995). The sexing of bovine embryos in the field. Theriogenology 43, 71-80.

Wood, T.C. \& Wildt, D.E. (1997). Effect of the quality of the cumulus-oocytes complex in the domestic cat on the ability of oocytes to mature, fertilize and develop into blastocysts in vitro. J. Reprod. Fertil. 110, 355-60.

Wood, T.C., Bayers, A.P., Jennette, B.E. \& Wildt, D.E. (1995). Influence of protein and hormone supplementation on in vitro maturation and fertilization of domestic cat eggs. J. Reprod. Fertil. 104, 315-23. 
Reproduced with permission of the copyright owner. Further reproduction prohibited without permission. 